\title{
DEVELOPING HIGH OIL SUNFLOWER HYBRIDS
}

Bâgiu, C.

S.C. Itc Ltd., Bd. Mârâsti, nr.61, 011464, Bucharest, Romania

Received: September 03, 2006 Accepted: September 15, 2007

SUMMARY

The paper is a synthesis of research issues concerning oil content in sunflower seeds and the relationship between seed oil contents in parent lines and their hybrids.

Key words: sunflower, hybrids, oil content

\section{INTRODUCTION}

Oil content in seed is an important target in sunflower breeding. High oil yield per unit area should be correlated with seed yield.

Oil content is generally considered as a quantitative trait (Vrânceanu, 1970; Gundaiev, 1971). First data regarding oil content inheritance emphasized the existence of a complex polygenic control with a significant additive gene action (Alexander, 1963).

Most literature data underline general combining ability for seed oil content as greater than specific one. This suggests that additive gene effects have a greater importance than the none-additive ones in the inheritance of oil content (Alexander, 1963; Vrânceanu and Stoenescu, 1969; Škorić, 1976; Rao and Sing, 1977; Ortegon-Morales et al., 1993). Kovačik and Škaloud (1972) reported very high nonadditive effects for oil content inheritance.

Škorić (1976) showed that a large number of $F_{1}$ hybrids contained partial or complete dominance, sometimes overdominance. His analyses demonstrated that both additive and non-additive effects were important.

Abdel Hamid (1980) mentioned that both additive and dominant gene effects are involved in the genetic control of sunflower seed oil content. Refoyo et al. (1988) found additive gene effects for oil content under dryland cropping and non-additive gene effects under irrigated conditions.

* Corresponding author: Phone: 004021-2234093; cellular phone: 004-0720366210; fax: 004021-2234299; e-mail: office@itcseeds.r 
We concluded that seed oil percentage is a variable feature that is strongly influenced by environmental factors; therefore, the heritability of this trait is complex.

\section{MATERIAL AND METHODS}

The experiment was performed in 2004. It included 50 sunflower hybrids tested in performance trials under dryland conditions at ITC, district Ilfov. Fifty inbred lines, parental forms (male sterile female lines and polyfertility restorer parental lines) were also studied. Oil content in the hybrids and parent lines was determined by the RMN method.

The agricultural year 2003-2004 was characterized by normal rainfall, close to the long-term average. Nitrogen and phosphorus fertilizers were applied as follows: $70 \mathrm{~kg}$ of phosphorus a.i./ha in the fall of 2003, and $50 \mathrm{~kg}$ nitrogen a.i./ha in the spring of 2004. The experimental data were processed by ANOVA. Statistical data evaluation of oil content inheritance was done by the two-factor analysis of variance following the Hardy-Weinberg law. Significance of the hybrids was estimated at LSD $5 \%$ level.

For the hybrids with oil content equal or higher than the average value, their oil content was considered to be controlled by a group of genes transmitted in block as a macrogene.

\section{RESULTS AND DISCUSSION}

In the first part of the paper, based on the oil content determined in seed at the parent lines and their hybrids, differences in average oil content were calculated between hybrids $v s$. female lines, hybrids $v s$. male lines and male $v s$. female lines.

The additivity hypothesis for the 9 significant hybrids, their oil content averages and standard deviations were calculated on the basis of the data presented in Table 1. In this group of hybrids, the oil content $(\mathrm{ULH} \%=52.97)$ was significantly higher than those of the parents and the hypothetical values. In that case, the additivity hypothesis does not verify, so that the non-additive relationships influence the transmission of the trait to the hybrid generation. It follows that for this kind of hybrids the selection of parents should be based on specific combining ability.

The analysis of correlations between hybrids as regards the oil content indicated that the female line significantly contributed to its increase while the male line diminished it.

For the hybrids with the oil content superior to the average, owing to the fact that all 12 hybrids had the oil content (ULH\%=50.94) superior to the hypothetic one $(\mathrm{AH}=40.02)$, the non-additive effects prevailed in the trait inheritance in the hybrid generation. In that case, the selection of parents should be based on specific combining ability too. 


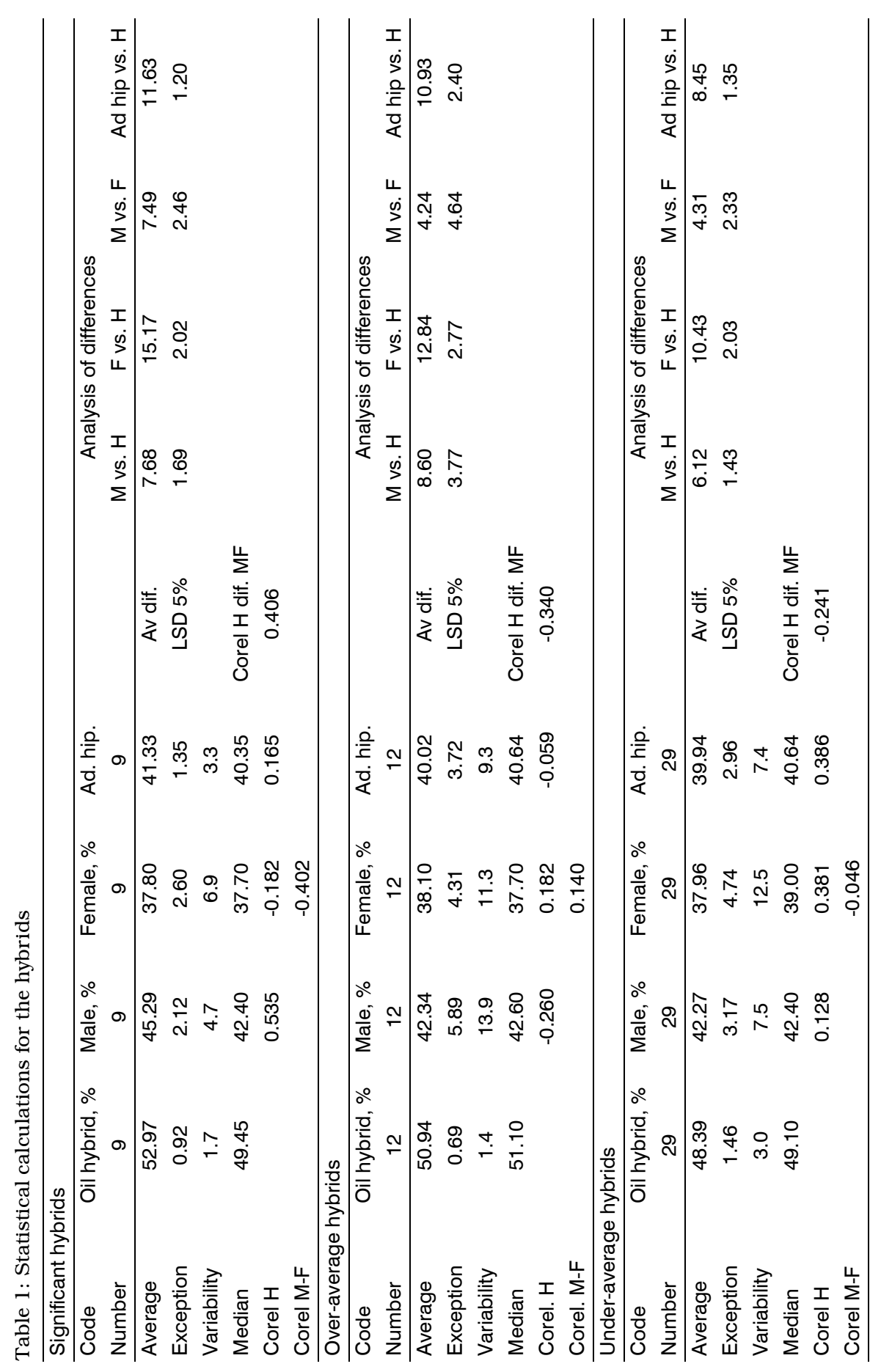


For these hybrids, the study of correlations indicated that the male line increased the oil content while the female one diminished it.

Twenty-nine hybrids had the average oil content inferior to the mean value of $48.39 \%$, but higher than the hypothetic value of $39.34 \%$. In that case, the additivity hypothesis again does not verify, the non-additive effects being important regarding the oil content transfer from the parents to the hybrids.

The analysis of correlations showed that both female and male lines had a positive contribution to oil content level.

In the case of 7 hybrids with the female line being significant for oil content inheritance, the average of $51.36 \%$ was higher than the hypothetic value $(\mathrm{AH}=42.47 \%)$, which leads to the conclusion that the additivity hypothesis does not verify. The non-additive effects prevail in the genetic control of the trait for this group of hybrids. In that case, the selection of parents should be based on specific combining ability (Table 2).

In the case of these hybrids, the female line contributed to oil content increase while the male line diminished it.

Eighteen hybrids had the oil content of the female line superior to the average value (Table 2 ). In these hybrids, the mean oil content $(50.60 \%)$ is superior to the hypothetic value (41.53\%), i.e., the additivity hypothesis does not verify. The nonadditive effects prevail in the transfer of this trait to the hybrids. In these hybrids, the non-additive relationships are important in the trait inheritance. The selection of parents should be based on specific combining ability.

Twenty-five hybrids with the seed oil content in the female line inferior to the average value ( $\mathrm{ULH} \%=48.84 \%$ ) had a lower hypothetic value $(38.83 \%)$, so that the additivity hypothesis does not verify and the non-additive relationships prevail in the transfer of this trait to the hybrids. In this type of hybrids, the selection of parents should be based on specific combining ability. In that case, the correlations show that the male line significantly contributes to the oil content increase while the female one diminishes it.

The hybrids with significant oil contents of the female and lines (Table 3) had the average oil content of $50.75 \%$ which was significantly higher than the values of the parents and the additivity hypothesis. It confirms the fact that the additivity hypothesis does not verify and that the non-additive relationships are important in the transfer of the trait to the hybrids. The selection of parents for crossing should be done on the basis of specific combining ability.

The hybrids with the superior oil content values of the female and male lines (Table 3 ) had the average oil content of 50.74 which was higher than the hypothetical value of 43.28 , indicating that the additivity hypothesis does not verify. In that case, non-additive effects are important in the transfer of the trait to the hybrid. In these hybrids, parents for crossing should be selected on the basis of specific combining ability. 


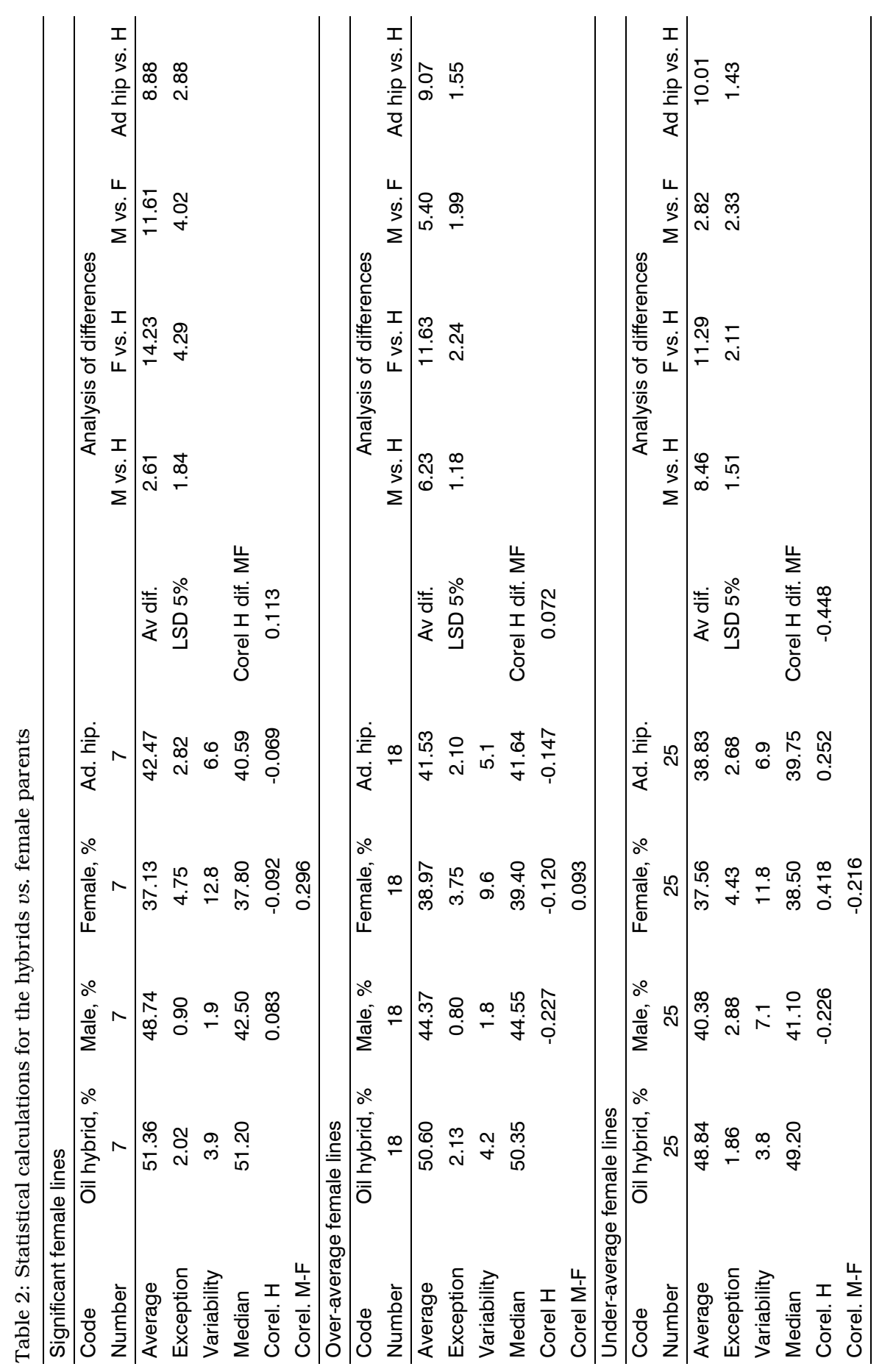









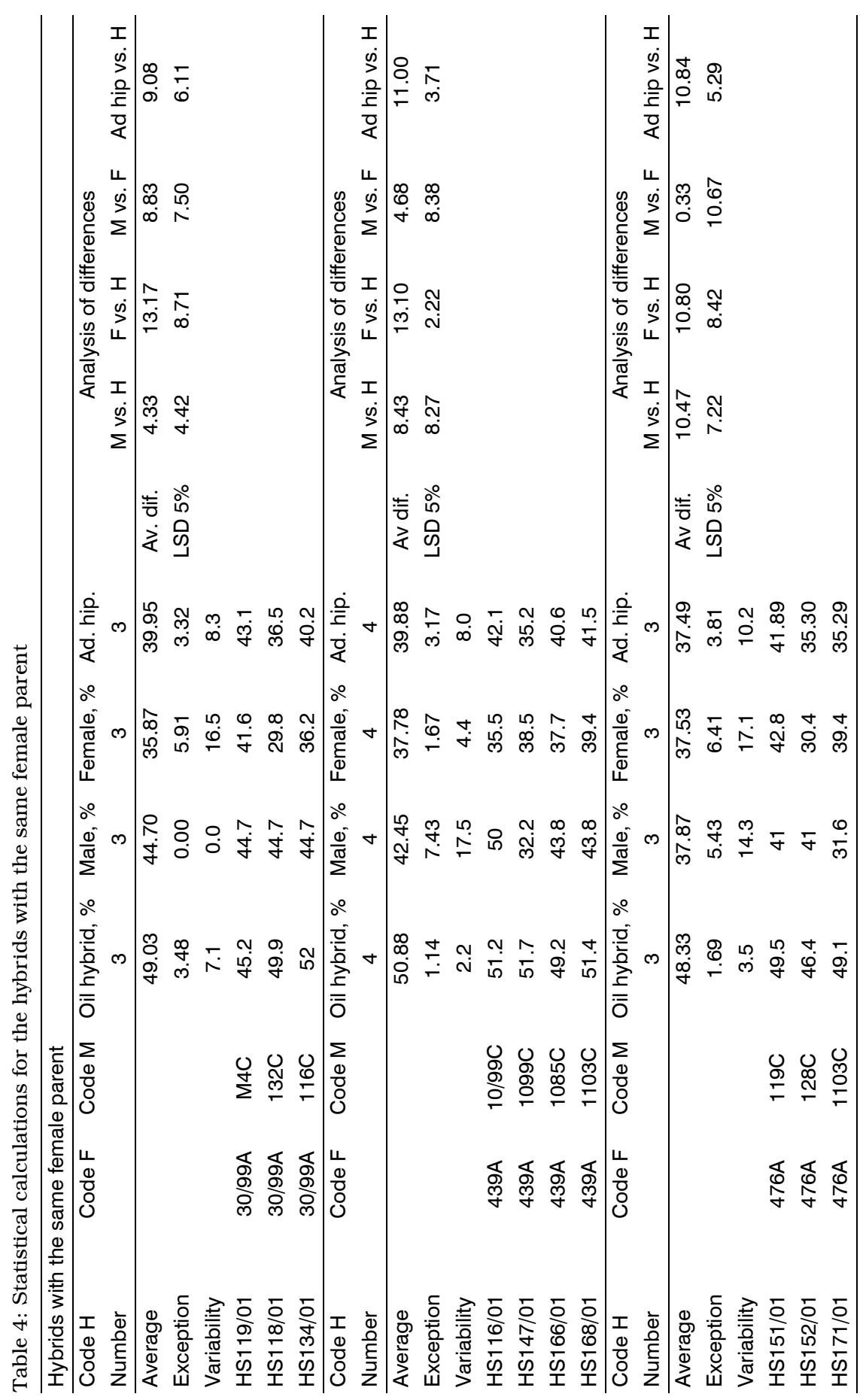


The analysis of oil content correlations demonstrated that in these 12 hybrids neither the female nor the male lines registered positive correlation coefficients. The female lines had a slightly increased contribution to hybrids' oil content.

The second part of the paper was aimed at verifying the additive and non-additive genetic control in hybrid groups with the same female or male line. The data presented in Table 4 show that when the line 30-99A is used as the female parent, the oil content will increase if the female line shows high general and specific combining ability while the male line shows high specific combining ability. The analysis of differences showed that the mean difference between the female line $v s$. hybrid was 4.33 and LSD5\% was 4.42 . In the case of the male line $v s$. hybrid, the mean difference was superior to the LSD5\% value (13.17 vs. 8.71, respectively).

When the line 439A is used as the female parent, the oil content will increased if it has a high general combining ability while the male parent has a high specific combining ability.

The oil content in the three hybrids which have the same female line, 476A, will increase if both parent lines have high general combining ability. This results from the higher value of the mean difference for $\mathrm{F} v s$. $\mathrm{H}$ than that for $\mathrm{M} v \mathrm{~s}$. $\mathrm{H}, 10.80$ and 10.47, respectively. The LSD 5\% values for $\mathrm{F} v$ s. $\mathrm{H}$ and $\mathrm{M}$ vs. $\mathrm{H}$ were lower than the average differences, 8.42 and 7.22 , respectively. The female line $v s$. male line correlation manifests an increased general combining ability, 10.67.

\section{CONCLUSIONS}

The obtained results allowed us to draw the following conclusions.

- In the hybrids with the same female parent, oil content will be increased when the female line has high general combining ability and the male line has high specific combining ability.

- In the hybrids with the same parents, oil content will be increased if both parents have high specific combining ability.

- The selection of parents for crossing for maximum oil content should be based on non-additive genetic control, the parent lines having high specific combining ability.

- The data on genetic control allow identification of efficient methods for oil content maximization. Their use in the breeding process helps to cumulate additive genes in progenies, i.e., to transfer additive polygenic blocks from highoil donor lines to lines with low seed oil content.

\section{REFERENCES}

Abdel Hamid El Hity, M., 1988. Some aspects of the inheritance of seed oil content in sunflower. Proc. $12^{\text {th }}$ Int. Sunflower Conf., Novi Sad, Yugoslavia. Vol. II: 471.

Alexander, D.E., 1963. The Lisenko method of increasing oil content of the sunflower. Crop Sci., 3: 279-280. 
Gundaiev, A.I., 1971. Osnovnie pointipi selektii podsolnecinka. Vestn. S.h. Nauki 10 (3): 124128.

Kovačik, A., Škaloud, V., 1972. Combining ability and prediction of heterosis in sunflower (Helianthus annuus L.). Scintia Agric. Bohemoslovaca T4, (XXI), Nr.4.

Ortegon-Morales, A.S., Mendoza, A.E., 1993. Aptitud combinatorial de hibridos de girasol (Helianthus annuus L.) para rendimiento de grono y aceite. Helia 16(19): 45-54.

Rao, N.M., Singh, B., 1977. Inheritance of some quantitative characters in sunflower (Helianthus annuus L.). Pontnagan J. Of Research 2(2): 144-146.

Refoyo, A., Martin, L.M., Serradilla, J.M., 1988. Herencia del contenido de aceite en los aquenios y almendras de girasol (Helianthus annuus L.). Proc. $12^{\text {th }}$ Int. Sunflower Conf., Novi Sad, Yugoslavia, Vol. II: 436-441.

Škorić, D., 1976. Mode of inheritance of oil content in sunflower seed of $F_{1}$ generation and components of genetic variability. Proc. $7^{\text {th }}$ Int. Sunflower Conf., Krasnodar, USSR. Vol. I: $376-388$.

Vrânceanu, A.V., Stoenescu, F.M., 1969. Hibrizii simpli de floarea-soarelui, o perspectiva apropiata pentru productie. Probleme agricole, 10: 21-32, Bucuresti.

Vrânceanu, A.V., 2000. Floarea-soarelui hibrida. Continutul de ulei din samânta. pp. 819-821, Bucuresti.

\section{CREACIÓN DE HÍBRIDO DE GIRASOL CON EL ALTO CONTENIDO DE ACEITE}

\section{RESUMEN}

Este trabajo representa la síntesis de los tópicos de investigación, relacionados con el contenido de aceite en la semilla de girasol y relaciones entre el contenido de aceite en las líneas progenitoras y sus híbridos.

\section{DÉVELOPPER DES HYBRIDES À HAUT RENDEMENT D'HUILE}

\section{RÉSUMÉ}

L'article est une synthèse sur les thèmes de recherche concernant le contenu d'huile dans les semences de tournesol et la relation entre le contenu d'huile des lignes parentales et les semences hybrides obtenues par le croisement des lignes parentales, croisement effectué dans le but d'établir des lignes pouvant maximaliser le contenu d'huile dans les semences. 
